Original research article

\title{
The Controversial Commemoration: Transnational Approaches to Remembering Bleiburg
}

\author{
VJERAN PAVLAKOVIĆ \\ University of Rijeka \\ DARIO BRENTIN \\ University of Graz \\ DAVOR PAUKOVIĆ \\ University of Dubrovnik
}

\begin{abstract}
Summary
This article provides an overview on some of the key issues related to the Bleiburg commemoration and more broadly the cultural memory of Partisan crimes at the end of the Second World War. Drawing upon four years of fieldwork, media analysis, and recent historiographical debates, the authors take a transnational approach in examining why Bleiburg remains one of the most controversial commemorations not just in Croatia but in the region. The article focuses on historical narratives in the commemorative speeches, the role of space in shaping memory politics, symbols and monuments present at Bleiburg Field, and the broader context of how Austrian politics affects the commemoration and its public perception.
\end{abstract}

Keywords: Bleiburg, Commemorations, Second World War, Victims of Communism, Symbols

\section{Introduction}

The Bleiburg commemoration continues to be one of the most controversial points of debate (along with Jasenovac) in Croatia regarding the Second World War, particularly after two successive right-wing coalitions came to power in 2016 on an anti-communist platform. ${ }^{1}$ Bleiburg, the Austrian town on the border with Slovenia where the armed forces of the Independent State of Croatia (NDH - Nezavisna

1 This special issue was made possible by generous funding from the Croatian Science Foundation (HRZZ - Hrvatska zaklada za znanost) through the project "Framing the Nation and Collective Identity in Croatia: Political Rituals and Cultural Memory of $20^{\text {th }}$ Century Traumas", and the 
Država Hrvatska) surrendered and were handed over to Tito's Partisans, symbolizes both communist crimes at the end of the Second World War and the legacy of communist authoritarianism more generally. The ideological divisions in contemporary Croatia, which continue to draw upon the symbolic legacies of either the Partisans or Ustaše, have saturated the political arena, media space, social networks, cultural production, sports, and many other aspects of everyday life even when most political observers agree that economic and demographic concerns are of greater importance. As many scholars in the field of memory studies have shown (Connerton, 1989; Assmann, 2004), in every society "we are constantly revising our memories to suit our current identities" (Gillis, 1994: 4-5). Political elites, as well as other social actors, use commemorative practices and other political rituals to not only construct a historical narrative, but secure legitimacy and power (Kertzer, 1988). While the general facts of the Bleiburg events are known (Grahek Ravančić, 2009; Hrženjak, 2007), the consequences of four decades of silence on communist crimes and uncertainty about the actual number of victims, and particularly where they are buried, means that this commemoration has been subject to considerable manipulation since Croatian independence. The genesis and development of the commemoration has resulted in its appropriation by nationalist and even radical right elements of the political spectrum, casting controversy on the manifestation through the use of controversial symbols and reinterpretations of the Second World War that cast the Ustaša forces as simply victims of communist repression and not Axis collaborators.

This article and others in the special issue are not investigating the actual events in May 1945, such as the nature of the communist repression or the identity of the victims, but rather seek to analyze the memorialization of Bleiburg through commemorative practices, historiographical debates, and media representations from a transnational perspective. The battles fought in the last weeks of the Second World War, followed immediately in the post-war period by executions of captured soldiers and perceived enemies of the people, resulted in tens of thousands of victims whose fate was often presented in black and white terms, i.e. either Ustaša killers who deserved to be executed or innocent victims killed only because they were Croats. This complex historical mosaic demands considerable future research by historians, anthropologists, legal scholars, and forensic specialists who can investigate archives and mass graves to shed light on the chronologies, locations, and identities of fallen soldiers and civilians who were killed in these tragic events. While it is the task of scholars to present a nuanced and objective as possible narrative of this chapter of the past, politicians, religious leaders, and other mnemonic actors involved in commemorating Bleiburg have the accountability to memorialize vic-

Croatian-Austrian Research Project "Transnational Culture of Memory of Bleiburg in Croatia and Austria" (HR 01/2016) financed equally by the Austrian Federal Ministry of Science, Research and Economy (BMWFW) and by the Ministry of Science and Education of the Republic of Croatia. 
tims with dignity, emphasize shared European democratic values, and refrain from distorting historical narratives for political interests. Observing the Bleiburg commemorations diachronically, it is possible to see that the commemoration remained controversial and subject to various manipulation, culminating in severe reactions by Austrian authorities regarding the banning of symbols in $2018 .^{2}$

Looking more broadly at Croatia's commemorative culture, it is possible to see that the memorialization is divided into "islands of memory" attended by separate communities of remembrance that rarely overlap. In other words, it is hard to imagine that participants attending Bleiburg would go to an antifascist commemoration such as Jasenovac, and during the research period of the FRAMNAT project it was possible to observe a sharp divide among the political leadership regarding which national level commemorations they would attend. ${ }^{3}$ For example, President Kolinda Grabar-Kitarović stopped attending the Jasenovac and Antifascist Struggle Day (Brezovica) commemorations, effectively contributing to the silencing of these memorial days, while former Prime Minister Zoran Milanović avoided attending the Victory Day and Homeland Thanksgiving commemorations in Knin due to verbal attacks by nationalists. Regarding Bleiburg, this has resulted in polarized perceptions of the commemoration, especially in media coverage and political discourse. On the one hand, for many leftists Bleiburg is exclusively a fascist gathering where the NDH is glorified and rehabilitated, without the acknowledgment that victims of communist crimes had been silenced for decades. On the other hand, many rightists claim that the commemoration merely pays respect to innocent victims, choosing to ignore or deny that many of the symbols and discourse at Bleiburg openly refer to the Ustaša regime. Since commemorations of traumatic events such as those related to the Second World War are about the public recognition of victims, the Croatian commemorative landscape has been subject to various struggles of overemphasizing or silencing one's own victims or the victims of the other side, resulting in competing narratives of Croatian statehood, identity, and political legitimacy.

Bleiburg has been a controversial commemorative space for decades, in fact almost immediately after the first secretive gatherings in the 1950s around Mother's Day. The origins of the commemoration and content of the commemorative speeches, both before 1990 and since Croatian independence resulted in official state involve-

2 “Bleiburg 2018: Ustaše, raus!”, Globus, 27 April 2018: 28-32; "Bleiburg u strogom civilu”, Jutarnji list, 13 May 2018: 4-5; "Čović: Više nego ikad nam je potrebno svehrvatsko jedinstvo", Večernji list, 13 May 2018: 4-5; "Skup u Blajburgu digao buru u Evropi”, Nezavisne novine, 13 May 2018: 14; "Ustaše ponovno divljale u Blajburgu”, Večernje novosti, 13 May 2018: 4-5. For an interview with Othmar Karas, one of the Austrian European parliamentarians who initiated the effort to ban or strictly monitor the Bleiburg commemoration, see Večernji list, 29 April 2018: 8-9.

3 For coverage of seven commemorations from 2014 to 2017 , see www.framnat.eu. 
ment, have been analyzed in a number of previous publications (Kolstø, 2010; Pavlaković, 2008; 2010). Davor Pauković (forthcoming) has argued that the myth of Bleiburg is not only important in understanding Croatian interpretations of the Second World War, but rather symbolizes a much broader period of communist violence and repression lasting up until the Croatian War of Independence (Domovinski rat, or Homeland War, 1991-1995). Christian Axboe Nielsen and Mate Nikola Tokić discuss the role of the Bleiburg myth and its enactment at commemorations during socialist Yugoslavia in the contributions to this special issue, while Martina Grahek Ravančić and Oto Luthar provide overviews of the historiography in Croatia and Slovenia, respectively. While the dominant perception, especially in Croatia, is that the communist crimes at the end of the war were directed only against Croatian collaborators, Jelena Đureinović and Amra Čusto show that other Yugoslav successor states likewise have memory politics that deal with victims of communist repression, even though they have tended to be overshadowed by the visibility of the Bleiburg commemoration. In addition, this article seeks to analyze some aspects of the Bleiburg commemoration that have characterized its perception in the public sphere and political discourse. For the left in Croatia, it is immediately associated with the radical right and the rehabilitation of the Ustaša movement, where symbols nominally forbidden in Croatia are openly displayed. For the right, the commemoration honors the Croatian victims of communist crimes and seeks to give voice to those whose memory was silenced for decades by Tito's regime. The media, various mnemonic actors, and the political elite have all spun mutually exclusive interpretations of the events at Bleiburg for their own communities of remembrance, rarely listening to the other side or attempting to place Bleiburg in the broader context of post-war Europe. For the researcher of Bleiburg, it is challenging not only to grasp the exact events of the spring and summer of 1945 across Yugoslavia and the neighboring countries with all of the entangled micro-histories, but requires considerable effort to push through the obfuscations, distortions, myths, constructed narratives, and politically charged representations that enshroud Bleiburg. These representations are reproduced annually by a variety of actors, many of whom can appropriately be labeled as memory entrepreneurs, since the commemoration, funded by the Croatian Parliament, is held on private land in a foreign country.

The themes we want to address in this article include the framing of the narrative, spatial characteristics of the commemoration, the international context of commemoration, specifically related to Austria, and the symbols present during commemorations. The speeches and mnemonic actors at Bleiburg are crucial in how the events of May 1945 have been framed. The FRAMNAT research project has collected and transcribed all of the speeches delivered at Bleiburg since 2014, but here only a few elements of the speeches and the key memory agents will be discussed. 
A more detailed discourse analysis can be found in the chapter by Davor Pauković in the edited volume Framing the Nation and Collective Identity in Croatia (forthcoming). Secondly, the spatial configuration of the commemoration affects not only the morphology of the ritual, but raises a number of questions about the importance of location and the ability of hosting a national memorial day in a foreign country. Thirdly, the transnational aspect of the commemoration, specifically in relation to Austria where the event is held, provides a view of the memorialization from a point of view other than just Croatia. The events in Carinthia at the end of the war resulted in a chaotic clash between various armies and masses of civilians caught in the middle, resulting in many different groups of victims that have been commemorated in various ways over the past seventy years. There is both understanding for the need to commemorate each group's victims as well as a separation between the individual groups with little overlapping commemorative practices. Finally, the presence of controversial symbols has always been present in the media reporting on the commemoration, and has been one of the arguments used by its opponents. Whether the use of symbols indicates actual fascist tendencies or is merely a marginal occurrence is an aspect of the commemoration that has not been previously analyzed.

\section{Narratives and Mnemonic Actors}

Closely tied to the issue of symbols, discussed in greater detail below, and who uses them, is the question of which narrative is being perpetuated at the commemorations, i.e., how is the recent past framed and what is actually being commemorated? Since the commemoration originated in the émigré community, primarily in Austria and Germany, these mnemonic actors were instrumental in directing the collective remembrance of the events of May 1945. Since the communist regime had ensured that memory of Bleiburg and other mass executions was taboo within Yugoslavia, apart from family memory and personal experiences, after the first democratic elections in 1990 the Croatian state simply appropriated the émigré narrative of Bleiburg when no others existed and no other place could be used to commemorate communist crimes. ${ }^{4}$ Current memorial sites like Macelj and Jazovka in Croatia and Tezno in Slovenia had either not yet been discovered or did not have the symbolic power of Bleiburg. Thus, Bleiburg and its pre-existing commemorative practices were uploaded into Croatia's repertoire of collective remembrance, initially alongside and eventually overtaking the emancipatory narrative of the antifascist victory in the Second World War. For the newly independent Croatia, Bleiburg had to be

4 The commemoration, which was attended by only a few hundred individuals prior to 1990 , was of course not the key producer of memory of Bleiburg, but rather it was the publishing activities of the Croatian diaspora, who wrote about the communist crimes in numerous books, pamphlets, and newspapers. See Geiger, 2003. 
a symbol and metaphor for not only communist crimes committed during the war and immediately after, but also for forty-five years of authoritarianism. This is further symbolized in the decision of the first post-Yugoslav government under Franjo Tuđman to officially declare the commemoration the Remembrance Day for Croatian Victims in the Struggle for Freedom and Independence (Dan spomena $\mathrm{na} \mathrm{hr}$ vatske žrtve u borbi za slobodu i nezavisnost) in 1996.

However, even though the Bleiburg commemoration symbolically covered a much broader series of events and victims, as reflected in the official speeches over the last twenty years, at its core much of the content remained surprisingly resistant to change. Despite contemporary speeches about innocent victims and civilians killed by communists, the Bleiburg commemoration was established by and for the fallen soldiers of the defeated Ustaša regime. This incomplete transformation into a true commemoration for victims of communism can partially be attributed to key organizers of the manifestation, the Bleiburg Honor Guard (PBV - Počasni bleiburški vod). They not only own the land where the commemoration is held, but they remain active in establishing the protocol and aesthetics of the ceremony, in close cooperation with the Catholic Church. As evident from the very name of the PBV, it retains its military connotations dating back to its formation in 1953. Another reason for the lingering glorification of the Ustaša forces has been the participation of political parties and supporters who continue to harbor sympathy for the NDH, the Ustaše, and their symbols since the 1990s (Pavlaković, 2008).

Former Ustaše located in Austria formed the PBV in 1953 with an explicitly military structure, and some of the key organizers (Ante Mikrut, Ilija Abramović, Jakov Radoš, and Mirko Karačić) had all been active in the NDH armed forces since the early stages of the war (Jurčević, Esih and Vukušić, 2005: 74-85). After functioning outside of the Austrian legal system for decades, the PBV officially registered in 1982 as the Croatian Cultural Organization Bleiburg (Hrvatsko kulturno društvo Bleiburg), and then re-registered in 2004 under its original name of Bleiburg Honor Guard (Počasni bleiburški vod/Bleiburger Ehrenzug) (ibid.: 162, 221-223). As the monument on Bleiburg Field clearly states, the site is dedicated to the "Honor and Glory of the Fallen Croatian Army". The military nature of the commemoration is evident from émigré publications, such as Hrvatska Država from Germany, which carried the headline "The Bones of our Fallen Call to Us: Croats Honor their Murdered Army at Bleiburg" in 1971. ${ }^{5}$ Once the Bleiburg commemoration became accessible to everyone from Croatia with the collapse of the communist regime in 1991, the narrative shifted from focusing on the fallen Croatian army to include an emphasis on civilian victims as Bleiburg became a symbol for com-

5 "Kosti naših nas zovu: Hrvati na Bleiburgu odaju počast svojoj pomorenoj vojsci", Hrvatska država, November-December 1971: 1. 
munist repression in general and not just related to the events in 1945. In a rhetorical shift, certain speakers at the Bleiburg commemoration and texts in the right-wing press even place the civilian victims first - women, children, and the elderly - and then also add the soldiers who surrendered, as if they were not the vast majority of those killed at Bleiburg. This is not to suggest that the killing of unarmed soldiers is less of a war crime (Vuletić, 2007), but deliberately creating a narrative in which civilians are allegedly the main victims of Partisan crimes distorts the true nature of the final battles in May 1945 and the extent of the new communist regime's settling of accounts with class enemies.

As is the case with Jasenovac, the number of victims of the Bleiburg massacres continues to be debated. While scholars have provided fairly consistent estimates (see Grahek Ravančić's contribution to this special issue), speeches given at the commemoration cite numbers drawn from earlier texts written by émigrés, with references to "hundreds of thousands of victims". ${ }^{6}$ For example, in 2014 the prefect of Split-Dalmatia County, Zlatko Ževrnja, stated in his speech at Bleiburg that "we are talking about around 200,000 murdered Croats". ${ }^{7}$ In 2016, Bishop of Banja Luka Franjo Komarica not only speculated on the number of victims, but their identity, stating that "the lives of tens, even hundreds of thousands of our fellow countrymen were extinguished - young and old, men and women, girls and children, Croats". 8 The same year, the speaker of the Parliament, Željko Reiner, also noted that "there is no doubt, and no one can deny it, that the communists committed a horrible

${ }^{6}$ Many scholars still cite demographer Vladimir Žerjavić's (1992) estimate of 45,000 to 55,000 Croats and 15,000 others (Slovenes, Serbs, Montenegrins, etc.) for a total of 70,000. Zdravko Dizdar (2005) notes that 62,000 have been identified by name from the territory of the NDH, but adds that estimates have ranged from 60,000 to 600,000. Martina Grahek Ravančić suggests that a total of 70,000-80,000 overall victims is a realistic estimate (2008: 868; 2009: 331). A 1946 report about the activities of OZNA, the Partisan intelligence services, notes that the Third Yugoslav Army captured over 100,000 enemy troops during the final operations in May 1945, and liquidated 35,000 of them, while the First Yugoslav Army reported that they liquidated about 7,000 "enemies of the people" after the Partisan units entered Zagreb. Arhiva vojnobezbednosne agencije, Istorija OZNE (1946), K-8, 6.303.2, sv. 1: 7, 23. The report explains how prisoners identified as Ustaše from 1941 to 1943 were immediately separated and executed, while those recruited since 1944 were investigated for possible crimes. Home Guards (Domobrani, the NDH's regular army) were usually released, although there were cases where they were also killed. The report for the Third Army notes that mistakes were made, such as the killing of 160 Home Guards by overzealous Partisans and the murder of twenty-two villagers by "Greater Serbian elements", all of which served to boost enemy propaganda (ibid.: 23-24).

7 Zlatko Ževrnja, Bleiburg, 17 May 2014, transcript at http://framnat.eu/bleiburg-transkripti/\#tabid-17.

${ }^{8}$ Bishop Franjo Komarica, Bleiburg, 14 May 2016, transcript at http://framnat.eu/bleiburgtranskripti/\#tab-id-6. 
crime by massively killing the unarmed members of the army, along with civilians, women, and children". "While there is evidence that a great number of civilians accompanied the retreating NDH forces, and that some civilians were killed, there has never been systematic research on the actual numbers, which allows for considerable manipulation and efforts to counter the Jasenovac narrative and victims (Grahek Ravančić, 2008: 851, 866-867). ${ }^{10}$

Besides the issue of the number and character of victims, critics of the commemoration accuse the participants of rehabilitating the NDH. While the rhetoric of the speakers has shifted over the past two decades, with certain politicians being harsher in their condemnation of communism and less critical of the Ustaše, an analysis of the speeches since 2014 indicates that despite statements referring to the evils of communism, fascism, and Nazism, none of the speakers explicitly condemned the Ustaša movement or the NDH. The narrative seeks to somehow separate the NDH from the totalitarian ideologies, and the communist crimes are portrayed without the context of as if the Croatian state during the war was somehow separate from the ideology of the regime that created it. The communist crimes are often described in a way as if they did not take place at the end of a bloody four-year war characterized by numerous war crimes and crimes against civilians, but as if the Partisans attacked a democratic Croatian state during peacetime. Since a number of speakers at Bleiburg seek to draw statehood continuity from the NDH to the modern Croatian state (Pauković, forthcoming), the efforts to discursively distance it from ideologies such as fascism and Nazism are understandable. The Mass performed by Bishop Mate Uzinić on 18 May 2014 is worth noting, since he was explicit in referring to Ustaša crimes as well as acknowledging the victims of Jasenovac, drawing praises across the political spectrum. ${ }^{11}$

9 Željko Reiner, Bleiburg, 14 May 2016, transcript at http://framnat.eu/bleiburg-transkripti/\#tabid-10.

${ }^{10}$ The debate about the nature of victims is frequently present in the media on the anniversary of the end of the Second World War, with both supporters and critics of the Bleiburg commemorations contributing opinion pieces in the press. For example, historian Ivo Lučić argues that "the regimes may have been different, but the victims are always the same - innocent". "Režimi su različiti, ali žrtve su uvijek iste - nevine", Globus, 18 May 2018: 35. Ivo Goldstein disagrees, stating that fascist and communist crimes can be compared but not equalized, since "Jasenovac was a crime of genocide, while Bleiburg and the Way of the Cross consisted of war crimes against captured and disarmed soldiers of an enemy army". "Bleiburg: Titov ratni zločin nad vojskom zla", Globus, 11 May 2018: 40.

${ }^{11}$ Transcript of speech by Bishop Mate Uzinić, 17 May 2014, online at http://framnat.eu/bleiburg-transkripti/\#tab-id-21. See also "Uzinićeva poruka najjača iz redova Crkve u 25 godina", Novi list, 19 May 2014: 7. 


\section{Space and Bleiburg}

The commemoration of the Bleiburg massacres and the Way of the Cross (Križni put, also referred to as the death marches) is specific to Croatia's commemorative calendar as it is the only one that takes place outside of Croatia. Although initially established by survivors of the NDH armed forces ${ }^{12}$ and used to remember the revenge carried out by the victorious Partisans against the defeated army, the commemoration now symbolizes more broadly communist repression against Croats in the post-war period. As the NDH collapsed in the face of Partisan forces in the final stages of the Second World War, the Ustaša political leadership, military units, and accompanying civilians fled the Partisan advance through Slovenia towards Austria, where they hoped to surrender to the Allies and escape communist retribution. Even though Germany capitulated on 8 May, the retreating NDH forces and other collaborationist units fought until 15 May, when the main body, soldiers and officers, attempted to surrender to the British at the Austrian town of Bleiburg. As per previous agreements between the Allied leadership, the British insisted they surrender to the Partisans, and sent the NDH soldiers who had previously surrendered back into Yugoslavia (Pavlaković, 2010: 128). The prisoners were sent on death marches into camps across Yugoslavia, while tens of thousands were liquidated without proper trials in mass graves in Slovenia and Croatia. In addition to NDH units, thousands of Germans, Montenegrin and Serbian Četniks, Slovenian White Guards, and Cossacks were likewise captured and/or killed in the chaotic and violent events throughout Southern Carinthia during the final weeks of the war (see Rulitz, 2016). There are therefore a number of memory sites throughout the Austrian-Slovenian-Italian border region that are related to killings and battles in the final stages of the war, including Viktring, Leinz, and Leše, to name a few (ibid.).

The commemoration begins with a Mass at the church and cemetery in UnterLoibach, where several NDH soldiers are buried. A procession led by clergy makes its way to the actual Bleiburg Field, where the PBV built a chapel and stage in 2007 to host the Mass and speeches. The original parcel of land was purchased in 1965, and after several additional purchases supported with donations from the Diaspora as well as the Croatian government, the current area owned by the PBV covers 30,000 square meters. ${ }^{13}$ In the past the political speeches came first and then Mass was held, but since 2015 the speeches are delivered after the religious ceremony, indicating the central role played by the Catholic Church. Analyzing the comme-

12 In 1944, the NDH combined the Ustaše units, considered to be the most ideologically fanatical troops responsible for most of the war crimes during the war, and Domobrani into a single organization, the Croatian Armed Forces (HOS - Hrvatske oružane snage).

13 "Zabranili i HOS. Austrijanci nemaju dvojbe: Taj grb ne smije na Bleiburg", Jutarnji list, 9 May 2018: 5. 
moration from a spatial perspective, it is possible to observe essentially three different areas of commemorative practices. The first space is the chapel and VIP seating area directly in front of the altar. Politicians and representatives of the PBV deliver official speeches from the stage, and the members of the clergy perform a Mass. Since the participants in the VIP area are sitting, controversial symbols are rarely displayed. Following the speeches, wreaths are laid at the nearby monument, accompanied by a military honor guard. The second commemorative space is the main part of the field, bordered on the far side by the elevated railroad tracks, which provides an excellent view of the entire area. The majority of participants gathers in this space, many of whom carry flags, banners, or clothing with some kind of national symbols. Although no systematic ethnographic research has been conducted to analyze the motivations for attending the commemoration, field observations indicate that there is a wide mix of Church groups, relatives of victims, religious pilgrims, political activists, and members of the Austrian and German diaspora, from all age groups. The participants in this area generally focus on the speeches on the stage, although there is more movement and conversation than in the VIP area.

The final area is a few hundred meters from the stage, where a number of tents and stands are set up to sell books, souvenirs, food, and alcohol. The participants here tend to display the greatest number of Ustaša symbols, and the sounds of songs, including those glorifying the NDH, can be heard coming from the tents as the commemoration progresses. The participants in this area pay little attention to the official program, and seem more focused on interacting with other like-minded individuals. The behavior in the tents tended to resemble a political gathering far more than the events in the main area of the field, where the atmosphere is more of a religious ceremony, and in the past journalists were threatened and attacked for trying to take pictures. In 2018, the Austrian authorities banned the selling of food, drinks, and souvenirs, clearly realizing that this was the most problematic aspect of the commemoration.

Since Croatian independence, not a single sitting president or prime minister has attended the commemoration, clearly indicating that even though the Parliament has funded the manifestation since 1995, every administration has felt it was too controversial to actually attend. The presidents of the Social Democratic Party of Croatia, which is the successor to the League of Communists of Croatia, have visited the Bleiburg memorial, including Ivica Račan, who apologized for communist crimes when he went there in 2002. Even prime ministers from the HDZ have avoided the commemoration, usually sending the speaker of the Parliament as the highest government representative. Ivo Josipović became the first president to visit the memorial, stopping first at Tezno before laying a wreath at Bleiburg on 20 June 2010. His gesture was particularly important since he brought with him a delegation 
of antifascists and representatives of Croatian Serb associations, ambitiously declaring that he "hoped to bring the story of the Second World War to an end and to make it part of history, but that every victim has a right to be buried in a grave". ${ }^{14}$ The president of the Croatian antifascist organization, Vesna Konstantinović Čulinović, laid a wreath at Tezno but did not go all the way to Bleiburg, stating that "there are no victims there, especially no innocent victims". ${ }^{15}$ Milorad Pupovac, president of the Serb National Council, echoed these arguments, stating that "Bleiburg is not a place of dying, but a place where ideologies and political values that I cannot accept and must be left behind us if we want to turn to the future are being restored". ${ }^{16}$

Whereas criticism of controversial symbols and the rehabilitation of the NDH can be heard from leftists, the lack of the physical remains of victims has increasingly served as an argument why Bleiburg is an inappropriate site. This is one of the arguments the SDP-led government of Zoran Milanović used for severing the Parliament's sponsorship of the commemoration, suggesting that the commemoration should take place either at Macelj (Croatia) or Tezno near Maribor (Slovenia) where the actual mass graves are located. ${ }^{17}$ The initiative was clearly intended to weaken the role of the PBV in coordinating the commemoration, but there is significance in the initiative since the presence of physical bodies increases the effect of the political ritual. The exhumation and reburial of Spanish Civil War victims plays a powerful role in Spain, giving the families of victims a chance to publicly display their grief after decades of the Francoist dictatorship, as well as forcing society to face the darker legacies of the past (Jerez-Farran and Amago, 2010; Renshaw, 2011). Understanding this, the PBV began building a military cemetery behind the monument on Bleiburg Field in 2010. Bodies of fallen NDH soldiers and others exhumed from mass graves would presumably be transferred to the cemetery, and the entire commemoration would begin here without the procession from Unter-Loibach. ${ }^{18}$ Although initially planned to be completed by 2011, work on the cemetery has come to a halt and no bodies have been transferred. In October 2016 several hundred bodies from the mass grave at Huda Jama were reburied near the monument in Tezno, which demonstrated the power of the physical presence of an ossuary.

14 “Josipović: Želim kraj priče o Drugom svjetskom ratu”, Novi list, 21 June 2010: 2.

15 Ibid.: 3 .

16 Ibid.

17 The members of Milanović's government claimed that the memory of victims "was misused and manipulated" at Bleiburg, so they planned a new memorial day and wanted to organize commemorations at killing sites that were part of the death marches. "Sabor odustao od odlaska u Bleiburg", Novi list, 18 April 2012: 6.

18 "Izgradnja hrvatskog vojnog groblja i spomen središta na Bleiburgu", Hrvatski tjednik, 4 March 2010: 17. 
Despite the greater "authenticity" of sites like Macelj or Tezno, Bleiburg remains the more powerful symbolic site of memory and will likely continue to function as the central commemorative space even with the new Austrian restrictions.

\section{Austria and the Transnational Aspect}

One aspect within historiographical debates about Bleiburg and its commemoration which is usually neglected, particularly in the Croatian historiographical debate, is a comprehensive local perspective and contextualization of Bleiburg within the complex Austrian memory landscape of the Second World War. Today, despite sporadic calls to transfer the commemoration to Croatia, it still takes place on Austrian soil even though the actual location was neither the place of heavy military fighting in 1945, nor of mass casualties or mass graves. This fact offers for a further transnationalization of the Bleiburg debate. Interestingly, Bleiburg as a place of Croatian national victimhood, has thus far also received relatively little attention in Austrian historiography, beyond scholars dealing with the post-Yugoslav memory politics (Radonic, 2010). The one exception from the rule is Florian Rulitz's (2011, published in English in 2016) historical analysis of what happened in Bleiburg and the Viktring, another small town in Carinthia, where after the Second World War over 10,000 Slovene Domobranci with their families where stationed, before being handed over to the Yugoslav Army. However, the reason why these events have received such limited scholarly interest may be found in the aforementioned local context of memory politics and remembrance of the Second World War.

Taking place in Austria's most southern province, Carinthia, one should point out that, even more than the Austrian context, the Carinthian one prevails as the dominant nexus that the Bleiburg debate should be interwoven into. The dominant historiographical debate, mirrored in an equally polarized popular narrative, identified the borderland of Carinthia as region in which, ever since the late 19th century, the culturally German majority had been under threat from within by its Slovene minority and from outside by the South Slav neighbors (Sima, 2006; Knight, 2010). The polarizing debate with ethno-national roots had been centered around questions of loyalty towards the Carinthian province and was further polarized by the socalled Carinthian Abwehrkampf (defense battle) of 1918/1919 and the pro-Austrian plebiscite vote in October 1920. The dominant narrative of the "Slav threat" in the region was cemented by the military resistance of Slovene Partisan units during the Second World War. As pointed out by Neugebauer (2009: 13-15), these units were the most vigorous military opposition to Nazi rule in today's Austria. Furthermore, for a brief period in May 1945, Yugoslav forces had entered the southern parts of the province with the goal of militarily establishing their claim to the area. The seizure of more than 200 Austrian nationals by the Yugoslav secret police OZNA in 
the areas where the fighting was particularly intense and the death of more than half of them has become part of the Carinthian Abwehrkampf narrative against Slavic violations (Knight, 2010). The construction of Carinthian victimhood vis-à-vis an omnipresent Slavic threat from within and from the outside explains the lack of interest in what had happened, partially on Austrian soil, but against non-Austrians. The multiple layers of constructed victims and perpetrators, that at times intersect, overlap and interchange, make for a complex scope of analysis that the two strands of historiography - Austrian and post-Yugoslav - have thus far not fully untangled. Furthermore, Austria's own struggles with coming to terms with its past, in other words, to reevaluate its self-perception as Hitler's first victim and to properly memorialize the victims of the Holocaust and Aryanization, contributed to the ambiguous response to revisionism during the Bleiburg commemoration (Bischof, 2004; Uhl, 2006).

\section{Bleiburg as a Symbol}

Since Croatia's independence in 1991, there is no doubt that Bleiburg has become the main symbol, or lieu de mémoire, of Partisan and communist crimes. The narrative of Bleiburg has multiple functions, so it can be observed through a number of different topics, approaches, and mnemonic actors (Bernhard and Kubik, 2014). Firstly, the debate on Bleiburg is a debate about Partisan crimes in the Second World War, that is, about the characteristics of the events at the end and immediately after the war. This includes topics related to the number of victims, the identity of the victims, their innocence or guilt regarding Ustaša crimes, whether it was primarily a retaliation typical for other Allied states, such as France (Lowe, 2013), or mostly a process of eliminating the "enemies of the people" and the establishment of a communist dictatorship. Secondly, Bleiburg is also an important symbol in the debate about communist Yugoslavia, especially for those who are critical of the second Yugoslav state established after 1945. After the collapse of communism in Croatia and the victory of the HDZ in the first multiparty elections, Bleiburg appeared for the first time in public discourse and became a symbol of the delegitimization of communist Yugoslavia. As can be seen in the database of commemorative speeches collected by FRAMNAT, many speakers at Bleiburg reject the antifascist narrative that Croatian statehood continuity was preserved through the Partisan struggle and suggest that the events of Bleiburg represent a disruption of Croatian desire for an independent state that was realized during the Homeland War. Thus, some right-wing political groups seek to connect the remembrance of the defeated NDH army with the veterans of Croatia's Homeland War in the 1990s. ${ }^{19}$ Finally, Bleiburg is also an

19 For a critical discussion of the meanings and interpretations of the Homeland War, see Jović, 2017. 
important symbol of historical revisionism. Although the commemorative practices at Bleiburg present an understandable critique of communist-based official history, which concealed communist crimes, they have also been used as a platform to rehabilitate the Ustaša regime and the NDH.

All of these topics in a broader sense are part of a nation-building process that began immediately after the communist defeat at the first multiparty elections in 1990. In that early period, Franjo Tuđman's concept of national reconciliation (of "the sons of Ustaša and Partisans") was a very important element (Đurašković, 2014). In that context, it was necessary to condemn the crimes of both totalitarian systems of the twentieth century. In that context, Tudman wanted to create a common monument for all Croat victims from the Second World War in Jasenovac, which provoked a negative response from the international community and led him to ultimately abandon this idea (Pavlaković, 2008). Although Tuđman's concept, which is also in the constitutional preamble, clearly emphasizes the merits of AVNOJ and $\mathrm{ZAVNOH}^{20}$ (in other words, the antifascist struggle) in contradiction to the NDH, since the 1990s various political, academic, and other public actors have debated the impact of the communist period in Croatia, including its legacy, on the nationbuilding process. That debate also includes Bleiburg, in a twofold sense. The first relates to the discussion of the events of May 1945, specifically regarding the fate of the victims, the opening of archives, and the exhumation of hidden mass graves. Responses to these questions also led to reappraisals of the character of the Yugoslav communist regime. The second discussion concerns the commemoration itself, or its main purpose, giving honor to the victims or the mourning and rehabilitation of the NDH. There is also a European context to this debate manifested through the European Parliament resolution on the condemnation of totalitarian regimes. ${ }^{21}$ This is a key argument in the narrative of those who support the Bleiburg commemoration and have a generally negative attitude towards the legacy of the communist Yugoslavia. Whereas prior to Croatia's EU accession left-wing parties called upon European values in order to restore legitimacy to the antifascist legacy, in the past five years the right-wing has been increasingly adept at using European discourse to justify the condemnation of communism. The critics of Bleiburg, however, claim that the NDH and communist Yugoslavia cannot be compared, and neither can the victims of Jasenovac and Bleiburg (Goldstein and Goldstein, 2011). Ultimately the debate about Bleiburg is also a debate about identity (religious, ethnic, ideological), involving many political and mnemonic actors with different motives and agendas.

20 The Antifascist Council for the People's Liberation of Yugoslavia (AVNOJ) and the Country Antifascist Council for the People's Liberation of Croatia (ZAVNOH) were the Partisan organizations that created both socialist Yugoslavia and the Socialist Republic of Croatia.

21 See Pauković, forthcoming. 


\section{Symbols at Bleiburg}

Commemorative spaces are places where it is possible to see many symbols, outfits, banners, and other visual expressions that contribute to the memory landscape and foster different narratives as well as inscribe meanings to the sites of memory investigated by FRAMNAT. ${ }^{22}$ Based upon the number of participants, averaging about 10,000 people every year, Bleiburg is the largest commemoration dealing with the Second World War in Croatian society. ${ }^{23}$ This commemoration also features the greatest number of symbols, many of them controversial, which have drawn considerable attention and ultimately led to the Austrian efforts to ban, or at least regulate, the manifestation.

The symbols at the commemoration can be divided into three groups. The first group consists of permanent symbols that are at the sites associated with the commemoration, such as monuments or various inscriptions. This group consists of monuments that the commemorative organizers, the PBV, have erected since the 1970s. The first monument is located in the Unter-Loibach cemetery, erected in 1976 and officially unveiled in 1977, where the commemoration begins with a prayer followed by the procession to the main stage at Bleiburg Field. The inscription was initially intended to include the phrase "the killed Croatian army" (pomorenoj hrvatskoj vojsci) but the local diocese did not allow it, and suggested using the "fallen Croatian army". ${ }^{24}$ The complete inscription reads "In honor and glory of the fallen, extradited to the Homeland, and disappeared Croatian Army in the struggle for the Croatian Homeland, May 1945". In the middle of the monument is an

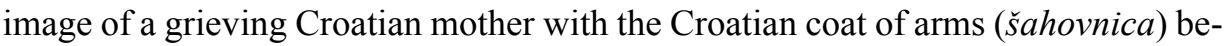
ginning with the white field. ${ }^{25}$ On the left side there is an image of the arisen Christ, while on the right side there is an Islamic crescent moon and star.

22 See www.framnat.eu for the photo archive of commemorations attended during the research project.

23 According to Austrian police and media reports, in 2014 there were "several thousand participants", in 2015 (the seventieth anniversary of Bleiburg) there were 20,000-30,000, in 2016 an estimated 15,000-20,000, while in 2017 and 2018 about 10,000.

24 "Počasni bleiburški vod podiže spomenike u Južnoj Austriji”, Dnevno, 15 May 2013.

25 The šahovnica, a chessboard coat of arms with alternating red and white fields, is a historic symbol originating some time between the eleventh and thirteenth centuries. Historically the šahovnica variously began with either a white or red field, but the Ustaša regime appropriated the white field first version and added the letter "U" above the coat of arms or in the corner of the official flag (Jareb, 2010). During Tito's Yugoslavia the šahovnica was part of the coat of arms of the Socialist Republic of Croatia (beginning with a red field first and with a red star), while the HDZ adopted the white field first version for its party flag and briefly as the official flag prior to the December 1990 elections. Interestingly, inserts illustrating historical Croatian flags and coats of arms in Večernji list, generally considered to be a right-leaning daily paper, did not include either the Ustaša flag or the short-lived HDZ flag among its list of official symbols. Večernji list, 9 and 10 October 2017. 
Figure 1. Memorial in Unter-Loibach cemetery

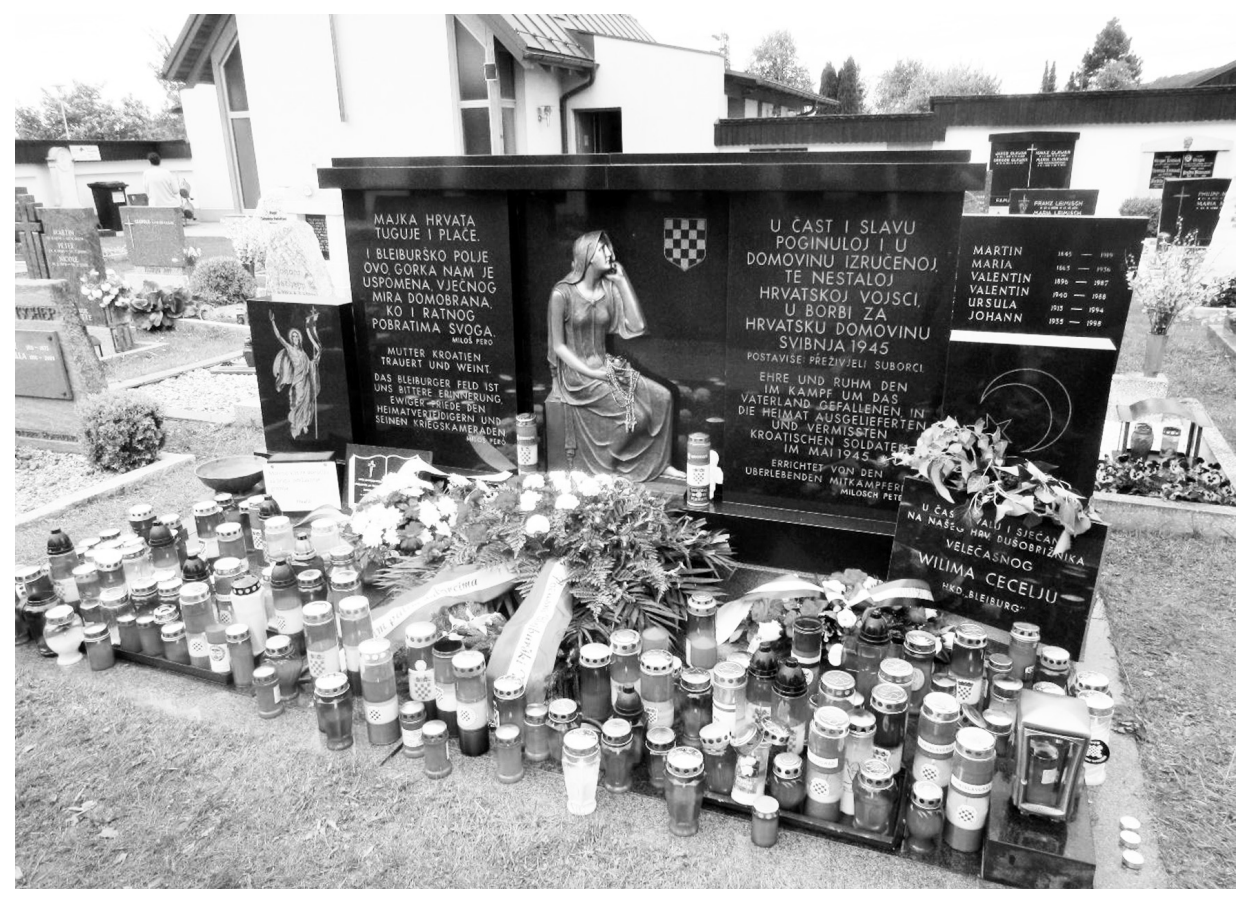

Photograph by Vjeran Pavlaković

The PBV erected the main monument on Bleiburg Field in 1987, with the inscription "In Honor and Glory of the Fallen Croatian Army, May 1945" in Croatian and German. As in the case of the Unter-Loibach monument, the Austrian authorities did not accept the inscription referring to the "killed Croatian army". It is also interesting that the German version of the inscription is different than the Croatian one. In the German version the word "army" was omitted, leaving only "In Memory of the Fallen Croats, May 1945" (Zum Gedenken an die gefallenen Kroaten, Mai 1945), which was another compromise so that the monument could appear. In 2004, the inscription was changed to "In Memory of the Innocent Victims of the Bleiburg Tragedy, May 1945". This change of the original inscription provoked conflicts inside the PBV, in which one group was asking for the return of the original inscription. ${ }^{26}$ This inscription was changed once again to include the national identity of

26 "Dramatično javno pismo predsjednika PBV-a", Hrvatsko slovo, 19 October 2007, http:// www.safaric-safaric.si/lokacija_bleiburg/bleiburg_200710/x200710\%20Bleiburg\%20PBV\%20 napis.htm. 
Figure 2. Memorial on Bleiburg Field

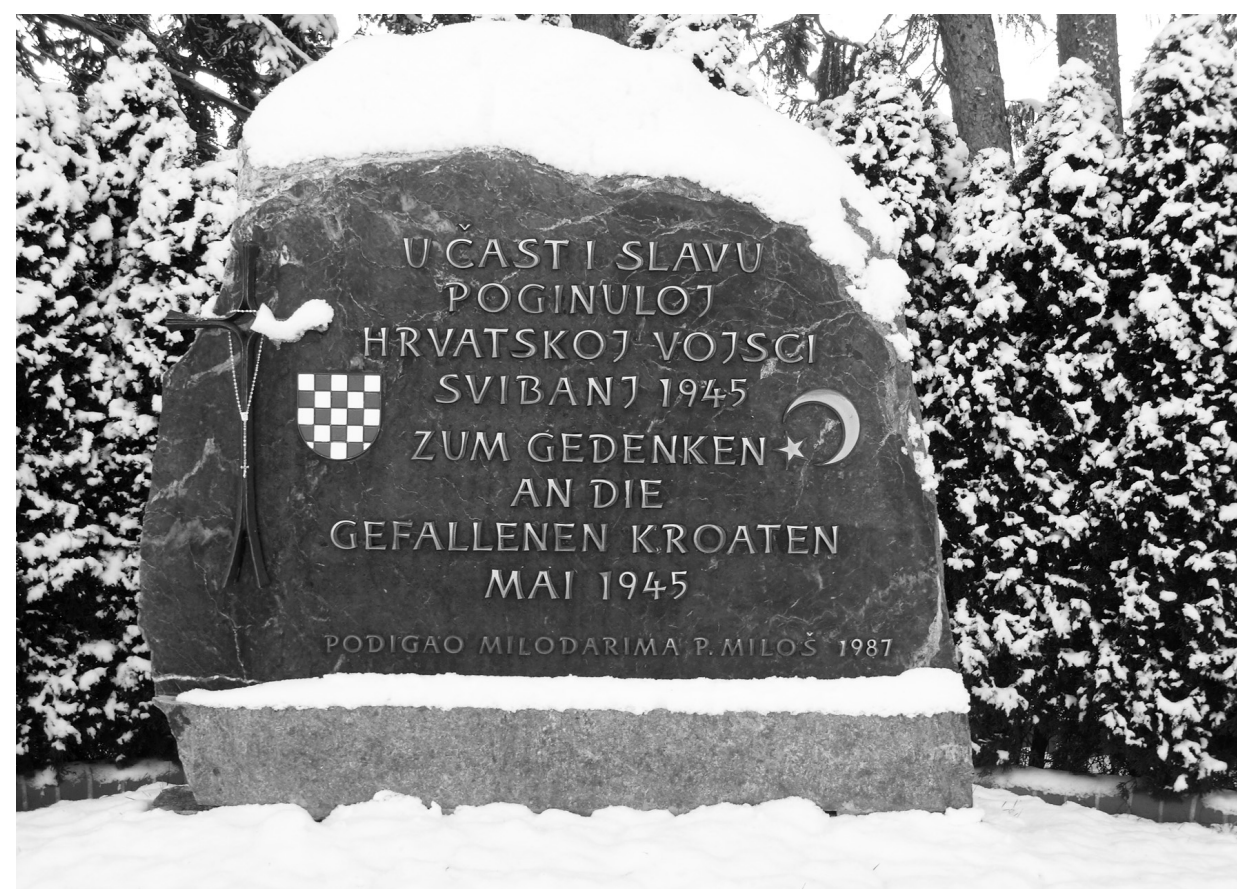

Photograph by Vjeran Pavlaković

the victims, so the text read "In Memory of the Croatian Victims of the Bleiburg Tragedy". After all of these debates about the inscription, the original text from 1987 was returned to the monument with the reference to the Croatian Army. Like the memorial in Unter-Loibach, this monument features the Croatian coat of arms, a cross, and the Islamic crescent moon and star.

A bust of Vilim Cecelja (1909-1989), a Croatian priest based in Salzburg and one of the key mnemonic actors in the first decades of the commemoration, was erected next to the main monument on Bleiburg Field. The monument lacks national symbols, but in addition to the dates of Cecelja's birth and death the pedestal has the following inscription: "Croatian priest, benefactor, guardian of Bleiburg memory".

The discussion about the inscriptions and the symbols on the monuments shows some of the basic elements that are often debated in relation to the Bleiburg events. The choice of words, killed or fallen, Croatian victims or just victims, civilians or soldiers, sends different messages and interpretations of the character of the events of May 1945. 
Figure 3. Members of the Croatian Party of Rights (HSP - Hrvatska stranka prava) hold flags of their party and HOS during Mass at Bleiburg Field in 2017

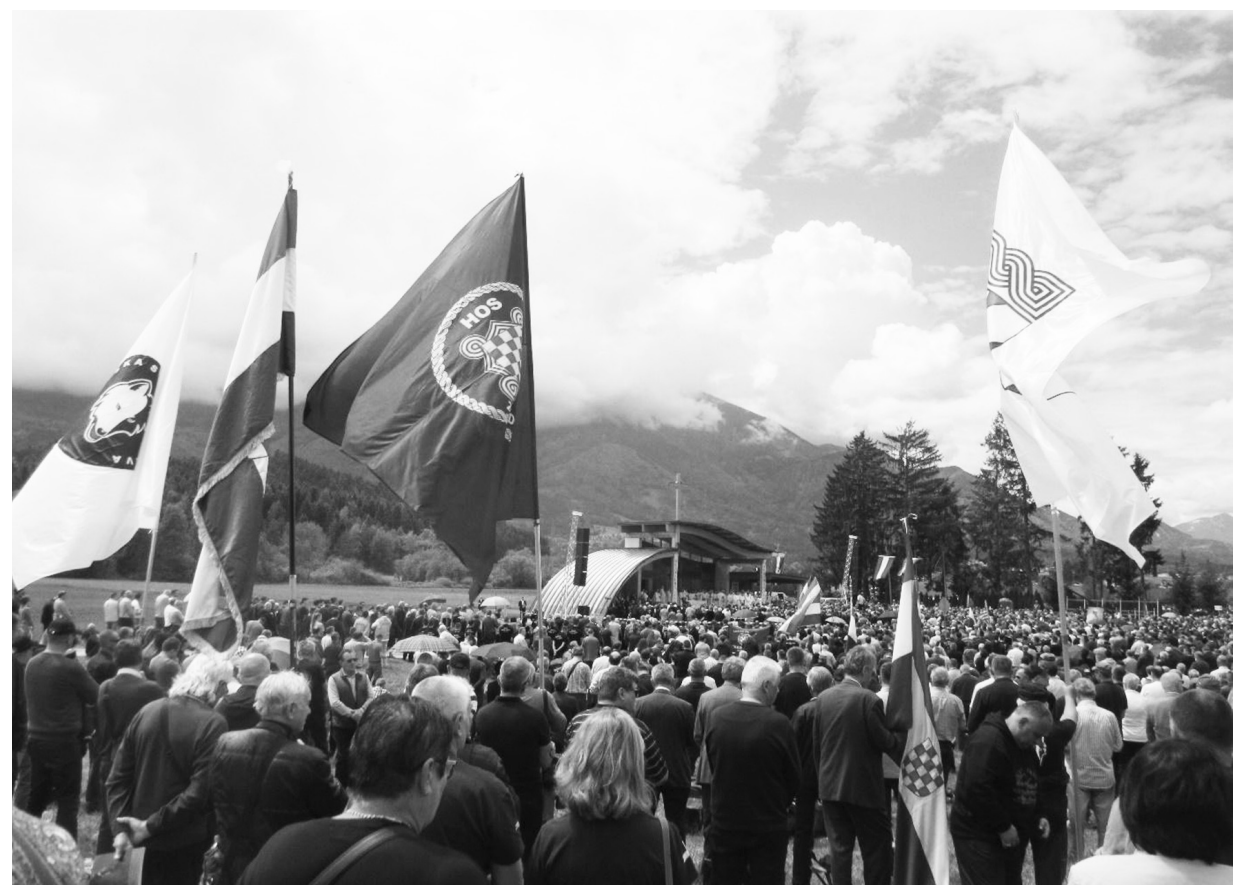

Photograph by Vjeran Pavlaković

The second group of symbols includes those used by the organizers of the commemoration. The PBV uses a flag designed in the 1960s with the Croatian tricolor and the PBV coat of arms, which consists of the Croatian coat of arms with the white field first situated within the traditional Croatian medieval heraldic border (pleter) above the initials PBV. The central part of the commemoration takes place in the small chapel erected by the PBV on Bleiburg Field. Inside the chapel the inscription "God Save Croatia!" is printed on a banner framed by the PBV coat of arms on either side, next to an official Croatian coat of arms. The flags of Croatia, Austria, and the European Union are situated close to the chapel and in front of the Bleiburg Field monument.

The third group represents the symbols used by the participants of the commemoration as well as the various mnemonic entrepreneurs and traders selling souvenirs and food. The most dominant symbol at the commemoration is the official Croatian flag with a šahovnica beginning with a red field and featuring the regional 
coats of arms. There are also many symbols of different associations and groups coming to the commemoration, including political parties and associations related to the Homeland War. Often, the flags include the name of the place where the participants come from, which assists in identifying the geographic origin of those attending the commemoration. For example, in the past few years while conducting fieldwork, researchers noted that many of the flags were from places in BosniaHerzegovina, such as Ljubuški, Široki Brijeg, Tomislavgrad, and Mostar. Informal observation of license plates of cars and buses parked near Bleiburg Field reveal a large number of Austrian and German vehicles, although many are also from Croatia. Flags from other countries are rarer, although occasionally American flags and even a Polish flag (with a banner referring to the Katyn massacre) can be seen. ${ }^{27}$

The most controversial symbols are those either explicitly referring to the NDH or those that can be interpreted in a variety of ways. Shirts, banners, and flags with the šahovnica beginning with a white field have been a common sight at Bleiburg. Critics of Bleiburg, and many leftists, immediately view this as a symbol of the NDH. However, during the period of political transition and after the first multiparty elections in 1990, flags with the white field first were widespread, which many Serbs and foreign correspondents also perceived as the return of Ustaša symbols. ${ }^{28}$ In July 1990, Amendment LXVI in the Constitution of the Socialist Republic of Croatia defined the coat of arms as the historical šahovnica consisting of twentyfive red and white fields, without indicating the color of the first field. ${ }^{29}$ Only with the December 1990 Constitution was the current flag and coat of arms adopted, featuring the red field first. As political scientists Charles Elder and Roger Cobb have noted,

when the symbols of politics are evoked, what is communicated is not strictly a function of the intent of the communicator nor of the manifest content of the message. The meaning of the message is heavily colored by the significance to the receiver of the symbols involved and his or her own interpretation of their meaning. The same symbols may communicate different things to different people (1983: 9-10).

${ }^{27}$ See the FRAMNAT photo collection for images of flags and symbols carried by participants 2014-2017, online at http://framnat.eu/bleiburg-framnat/.

${ }^{28}$ During the war crimes trial of Milan Martić, a former president of the Republika Srpska Krajina parastate and onetime police chief of Knin, witnesses testified that one of the reasons his police rebelled against Zagreb was that they refused to wear Ustaša symbols, i.e. the šahovnica, on the new police uniforms. Transcripts of trial of Milan Martić, testimony of Milan Babić, 15 February 2006. Online version at http://www.icty.org/x/cases/martic/trans/en/060215ED.htm, accessed 5 March 2018.

${ }^{29}$ Odluka o proglašenju Amandmana LXIV. do LXXV. na Ustav Socijalističke Republike Hrvatske, NN 31/1990, https://narodne-novine.nn.hr/clanci/sluzbeni/1990_07_31_610.html. 
Figure 4. Souvenir stand selling flags and t-shirts displaying the šahovnica with a white field first and image of an NDH soldier with the same coat of arms

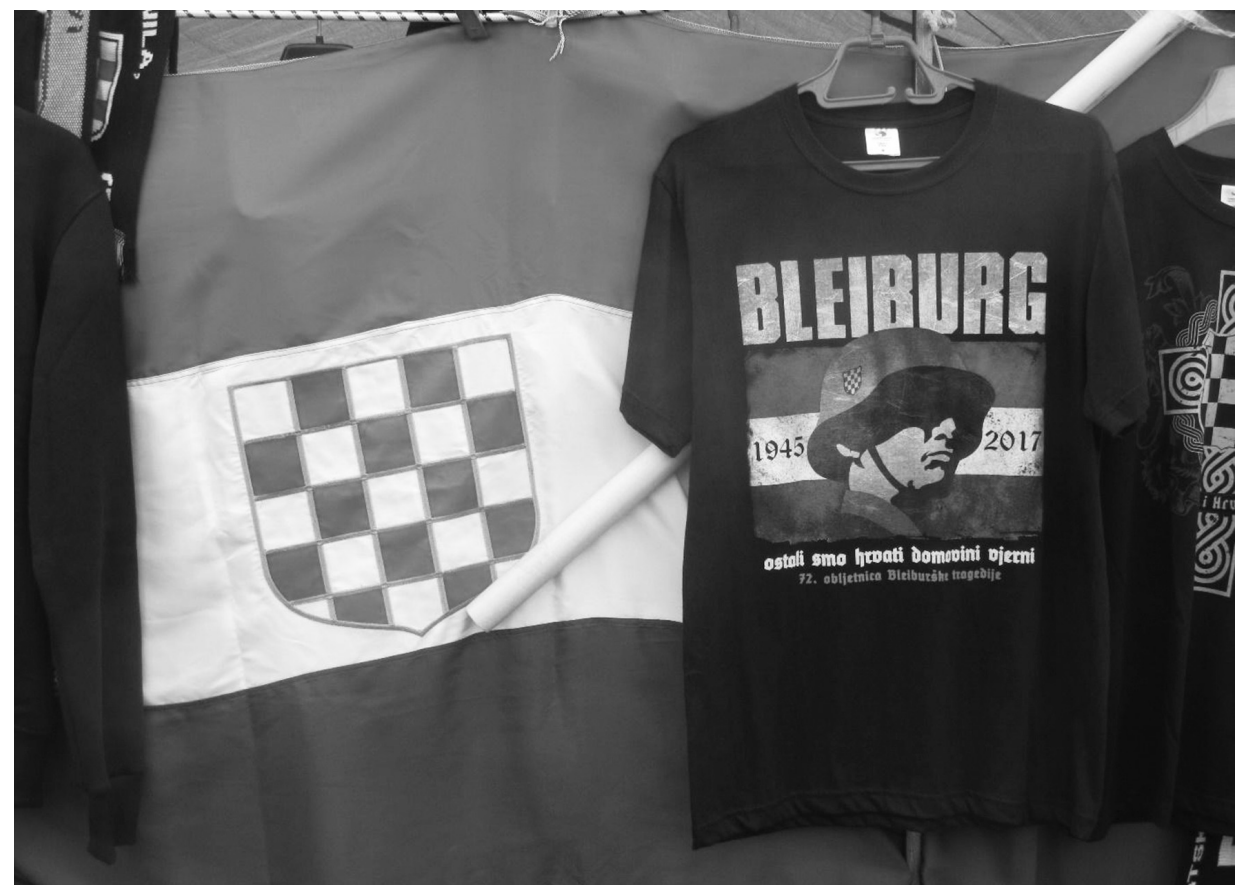

Photograph by Vjeran Pavlaković

Thus, the meaning of the white field first continues to divide public opinion. The argument of those who display this version claim that it is a legitimate Croatian historical flag. ${ }^{30}$ Others question why use a flag that contains symbols alluding to the NDH when the official Croatian flag is readily available and abundant. As many studies on collective memory have shown, symbols and iconography play an important part in commemorative practices, so the use of a particular image tends to be a deliberate statement by the user, such as the decision by some American nationalists to carry a Confederate battle flag as opposed to the official US flag (Blight, 2001; Schwartz, 1982: 377). It should also be noted that the šahovnica with the white field first was among the banned symbols determined by the Austrian authorities, clearly

${ }^{30}$ In a long interview about symbols and commemorations, the president of the Croatian Helsinki Committee, Ivan Zvonimir Čičak, rejected any association of the white field first with the Ustaša regime, although he did admit that the official Croatian flag started with a red field. "Treba nam istina o Jasenovcu: Činjenice, a ne procjene", Globus, 11 May 2018: 16-17. 
Figure 5. Selling souvenirs with Za dom spremni at Bleiburg, 2017

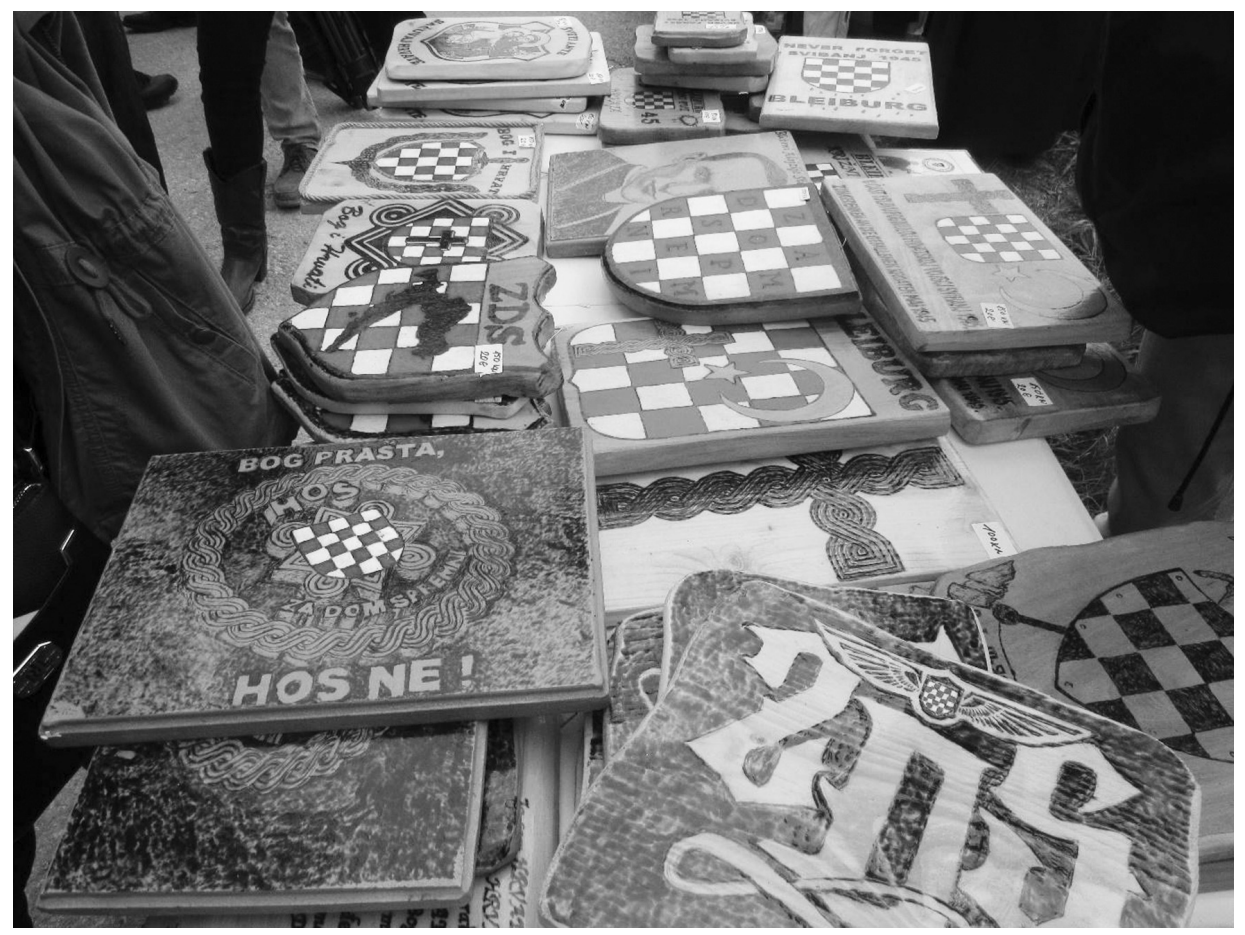

Photograph by Vjeran Pavlaković

indicating that they consider it a symbol that had been used by allies of the Nazi regime. Future research about the decision to use a certain version of the šahovnica could reveal whether people simply see it as a legitimate Croatian symbol or if they choose the white field first because of its ideological connotation. But there is little doubt that it is associated with right-wing political parties and is present at most commemorations dealing with communist crimes.

The most controversial symbols and uniforms are those that explicitly refer to the Ustaša regime and the NDH. It is important to emphasize that in the last four years of fieldwork at Bleiburg, only a handful of people each year were seen with explicit Ustaša symbols, and in some cases they were the same people every year, although in the past Ustaša uniforms were more common. In recent years, the PBV sent messages before the commemoration asking participants not to wear Ustaša symbols to prevent them from compromising the event (Pauković, forthcoming). The international as well as the Croatian media always pay close atten- 
tion to the presence of Ustaša symbols, although many times those wearing them are not close to the main stage, or journalists choose not to mention them in their articles. ${ }^{31}$ In previous years Austrian police were oblivious to the openly displayed Ustaša flags and badges, stating that on this day "Croats are allowed to use their symbols". ${ }^{32}$ Other symbols include the "U" symbol, maps of the NDH, pictures of Ante Pavelić, lines from Ustaša songs printed on shirts, and in recent years increasingly Za dom spremni (Ready for the Homeland, the Ustaša salute). ${ }^{33}$ The use of this salute on a monument near the Jasenovac Concentration Camp memorial site in 2017 sparked extensive debates (Pavlaković, 2018), and led to the formation of a government commission dealing with totalitarian symbols that concluded $\mathrm{Za} \mathrm{dom}$ spremni should be banned except in specific instances when it is associated with the Homeland War. ${ }^{34}$

\section{(Un)certain Future?}

Since the regular Bleiburg commemorations were established in the 1950s, Austrian authorities have displayed relatively little interest in them (see the article by Christian Axboe Nielsen in this special issue). Apart from sporadic media reports and protests from leftist parties and organizations from the 1980s onwards, it was not until the early 2010 s that the topic started gaining nationwide traction on a yearly basis. ${ }^{35}$ The arguable turning point that saw a significant shift in the debate was the seventieth anniversary of the commemoration in 2015. The sheer number of people that was present that year, with estimates going up to 50,000 participants, as well as the increasing numbers of Ustaša symbols and other fascist paraphernalia led to an increased discussion of the commemoration in the media and beyond. Austrian authorities, however, still reiterated their position that the commemoration itself is a religious manifestation, where the state had no possibility of intervening in its con-

31 While attending the Bleiburg commemoration in 2007, the journalist and photographer for Vjesnik, a former government-controlled daily, were given instructions not to report on Ustaša symbols or print any images of them.

32 Author's fieldnotes, Bleiburg, 15 May 2010.

${ }^{33}$ For an analysis of the use of Za dom spremni at sporting events and other public spaces in Croatia, see Brentin, 2016.

34 The final report on undemocratic symbols, titled "A Document of Dialogue", is available in pdf at https://www.tportal.hr/vijesti/clanak/evo-sto-je-zakljucilo-vijece-za-suocavanje-s-prosloscu-20180228.

35 In 2009, Globus reported on the activities of Austrian antifascists who were protesting the commemoration by the radical right at Ulrichsberg and connecting it with the Bleiburg commemoration. "Hrvati, nećete više u Bleiburg", Globus, 25 September 2009: 32-36. 
tent, as well as pointing out that the symbols in question where not illegal in Austria. In the following years, the debate remained ever more contentious.

The 2018 commemoration has thus far been the most widely debated, with the debate going beyond "the usual circles". Political pressure came from four Austrian MEPs from four different parties and other NGOs, who gave a joint press conference calling the Bleiburg commemoration the "biggest gathering of fascists" in Europe. ${ }^{36}$ The increased scrutiny over the commemoration's character prompted the diocese of Gurk, which allows for the event being organized by the Croatian Catholic Church in Bleiburg, to make a press statement demanding there be no alcohol, political speeches, or any fascist and Ustaša symbols and paraphernalia. The Austrian police were very strict in controlling and preventing the wearing of any symbol that could be connected to the NDH or Axis forces, although journalists in private communication with the authors noted that some people had nonetheless displayed this iconography. For many of the critics of the Bleiburg commemoration, explicit Ustaša symbols are the main argument against supporting the event. While there was less visible fascist symbols due to increased securitization of the entire event, some international reports pointed out that the ideological content of the commemoration did however not change significantly. ${ }^{37}$ Nevertheless, the Austrian controls, supported by statements from the Catholic Church in Carinthia that oversees the event, seemed to limit at least the visuals of NDH rehabilitation, and the ban on souvenir, food, and alcohol sales eliminated elements of the commemoration that fueled criticism that it was becoming "Europe's biggest neo-fascist gathering". ${ }^{38}$ The developments and fierce debates in Austria during 2018 over the Bleiburg commemoration indicate that future events might face more significant opposition or obstacles by local authorities, the Austrian state or the diocese of Gurk, potentially making it impossible to have the commemoration on Austrian soil. However, despite a potentially uncertain future of the Bleiburg commemoration in Austria, it is certainly unquestionable that whilst the commemoration might change its nature or even location, "Bleiburg" will remain a central point of political contestation within the Croatian memory landscape.

36 Schmidt, Colette. EU-Abgeordnete warnen vor Ustascha Treffen in Bleiburg, Der Standard, 23 April 2018, https://derstandard.at/2000078493494/EU-Abgeordnete-warnen-vor-UstaschaTreffen-in-Bleiburg.

37 Majic, Danijel. Die Ustascha im Herzen, Frankfurter Rundschau, 15 May 2018, http://www. fr.de/politik/kroatien-die-ustascha-im-herzen-a-1505508

38 Hopkins, Valerie. Croatia's contested commemoration, Politico, 17 May 2018, https:// www.politico.eu/article/croatia-contested-commemoration-world-war-ii-nationalists-catholicchurch/. 


\section{REFERENCES}

Assman, Aleida. 2004. Four Formats of Memory: From Individual to Collective Constructions of the Past, in: Christian Emden and David Midgley (eds.): Cultural Memory and Historical Consciousness in the German-Speaking World since 1500. Bern: Peter Lang.

Bernhard, Michael and Kubik, Jan, eds. 2014. Twenty Years after Communism: The Politics of Memory and Commemoration. Oxford: Oxford University Press.

Bischof, Günter. 2004. Victims? Perpetrators? "Punching Bags" of European Historical Memory? The Austrians and Their World War II Legacies. German Studies Review, (27), 1: 17-32.

Blight, David W. 2001. Race and Reunion: The Civil War in American Memory. Cambridge, Mass.: Harvard University Press.

Brentin, Dario. 2016. Ready for the homeland? Ritual, remembrance, and political extremism in Croatian football. Nationalities Papers, (44), 6: 860-876.

Connerton, Paul. 1989. How Societies Remember. Cambridge: Cambridge University Press.

Dizdar, Zdravko. 2005. Prilog istraživanju problema Bleiburga i Križnih puteva. Senjski zbornik (32).

Đurašković, Stevo. 2014. Nation-building in Franjo Tuđman's Political Writings. Politička misao, (51), 5: 58-79.

Đurašković, Stevo. 2016. National identity-building and the "Ustaša-nostalgia" in Croatia: the past that will not pass. Nationalities Papers, (44), 5: 772-788.

Elder, Charles D. and Cobb, Roger W. 1983. The Political Use of Symbols. New York: Longman.

Geiger, Vladimir. 2003. Osvrt na važniju literaturu o Bleiburgu 1945. Časopis za suvremenu povijest, (35), 1: 189-216.

Gillis, John R., ed. 1994. Commemorations: The Politics of National Identity. Princeton, N.J.: Princeton University Press.

Goldstein, Ivo and Goldstein, Slavko. 2011. Jasenovac i Bleiburg nisu isto. Zagreb: Novi liber.

Grahek Ravančić, Martina. 2008. Razmišljanja o broju pogubljenih i stradalih na Bleiburgu i križnom putu. Časopis za suvremenu povijest, (40), 3: 851-868.

Grahek Ravančić, Martina. 2009. Bleiburg i križni put 1945. Zagreb: Hrvatski institut za povijest.

Hrženjak, Juraj, ed. 2007. Bleiburg i Križni put 1945. Zagreb: Savez antifašističkih boraca i antifašista Republike Hrvatske.

Jareb, Mario. 2010. Hrvatski nacionalni simboli. Zagreb: Hrvatski institut za povijest. 
Jerez-Farran, Carlos and Amago, Samuel. 2010. Unearthing Franco's Legacy: Mass Graves and the Recovery of Historical Memory in Spain. Notre Dame: University of Notre Dame Press.

Jović, Dejan. 2017. Rat i mit. Zagreb: Fraktura.

Jurčević, Josip, Bruna Esih and Bože Vukušić, eds. 2005. Čuvari bleiburške uspomene, 2nd ed. Zagreb: Klub hrvatskih povratnika iz iseljeništva.

Kertzer, David I. 1988. Ritual, Politics, and Power. New Haven: Yale University Press.

Knight, Robert. 2010. Transnational memory from Bleiburg to London (via Buenos Aires and Grozny). Zeitgeschichte, (38), 1: 39-53.

Kolstø, Pål. 2010. Bleiburg: The Creation of a National Martyrology. Europe Asia Studies, (62), 7: 1153-1174.

Lowe, Keith. 2103. Savage Continent: Europe in the Aftermath of World War II. New York: Penguin.

Neugebauer, Wolfgang. 2009. Bewaffneter Widerstand - Widerstand im Militär: Ein Überblick, in: Christine Schindler (ed.): Schwerpunkt: Bewaffneter Widerstand - Widerstand im Militär. Jahrbuch des Dokumentationsarchivs des österreichischen Widerstands 2009, Hrsg. Dokumentationsarchiv des Österreichischen Widerstandes. Wien, Berlin, Münster: LIT: 12-36.

Pauković, Davor. Forthcoming. Framing the narrative about communist crimes in Croatia: Bleiburg and Jazovka, in: Vjeran Pavlaković and Davor Pauković (eds.): Framing the Nation and Collective Identity in Croatia. New York: Routledge.

Pavlaković, Vjeran. 2008. Flirting with Fascism: The Ustaša Legacy and Croatian Politics in the 1990s, in: Darko Gavrilović (ed.): The Shared History and the Second World War and National Question in ex-Yugoslavia. Novi Sad: CHDR.

Pavlaković, Vjeran. 2010. Deifying the Defeated: Commemorating Bleiburg since 1990. L'Europe en Formation, (357): 125-147.

Pavlaković, Vjeran. 2018. Sukobljena jasenovačka kultura sjećanja: postkomunistički memorijalni muzej u Jasenovcu u doba povijesnog revizionizma, un: Andriana Benčić, Stipe Odak, Danijela Lucić (eds.): Jasenovac: manipulacije, kontroverze $i$ povijesni revizionizam. Jasenovac: Spomen područje Jasenovac.

Renshaw, Leyla. 2011. Exhuming Loss: Memory, Materiality and Mass Graves of the Spanish Civil War. New York: Routledge.

Radonic, Ljiljana. 2010. Krieg um die Erinnerung. Kroatische Vergangenheitspolitik zwischen Revisionismus und europäischen Standards. Frankfurt am Main: Campus.

Rulitz, Florian Thomas. 2011. Die Tragödie von Bleiburg und Viktring. Partisanengewalt in Kärnten am Beispiel der antikommunistischen Flüchtlinge im Mai 1945. Klagenfurt: Hermagoras Verlag.

Rulitz, Florian Thomas. 2016. The Tragedy of Bleiburg and Viktring, 1945. Translated by Andreas Niedelmayer. DeKalb, IL: Northern Illinois University Press. 
Schwartz, Barry. 1982. The Social Context of Commemoration: A Study in Collective Memory. Social Forces, (61), 2: 374-402.

Sima, Valentin. 2006. Zwischen Mythen und Realität. Erinnerungspolitik in Kärnten nach 1945. Mitteilungen der Alfred Klahr Gesellschaft, (13), 2: 27-30.

Uhl, Heidiemarie. 2006. From Victim Myth to Co-Responsibility Thesis: Nazi Rule, World War II, and the Holocaust in Austrian Memory, in: Richard Ned Lebow, Wulf Kansteiner, and Claudio Fogu (eds.): The Politics of Memory in Postwar Europe. Durham, N.C.: Duke University Press.

Vuletić, Dominik. 2007. Kaznenopravni i povijesni aspekti bleiburškog zločina. Pravnik, (41), 2: 125-150.

Žerjavić, Vladimir. 1992. Opsesije i megalomanije oko Jasenovca i Bleiburga. Zagreb: Globus.

Vjeran Pavlaković is Associate Professor at University of Rijeka.

Dario Brentin is University Assistant at Centre for Southeast European Studies, University of Graz.

Davor Pauković is Assistant Professor at University of Dubrovnik.

Mailing Addresses:

Vjeran Pavlaković, Faculty of Philosophy, University of Rijeka, Sveučilišna avenija 4, 51000 Rijeka. E-mail: vjeran.pavlakovic@uniri.hr

Dario Brentin, Centre for Southeast European Studies, University of Graz, Universitatspl. 3, 8010 Graz, Austria.E-mail: dario.brentin@uni-graz.at

Davor Pauković, Odjel za komunikologiju, Sveučilište u Dubrovniku, Branitelja Dubrovnika 29, 20000 Dubrovnik.E-mail: davor.paukovic@unidu.hr 